\title{
Alterations of PTEN and SMAD4 methylation in diagnosis of breast cancer: implications of methyl II PCR assay
}

\author{
Menha Swellam¹, Entsar A. Saad ${ }^{2}$, Shimaa Sabry², Adel Denewer ${ }^{3}$, Camelia Abdel Malak $^{2}$ and Amr Abouzid ${ }^{3}$
}

\begin{abstract}
Background: Diagnosis of breast cancer is more complicated due to lack of minimal invasive biomarker with sufficient precision. DNA methylation is a promising marker for cancer diagnosis. In this study, authors evaluated methylation patterns for PTEN and SMAD4 in blood samples using EpiTect Methyl II QPCR assay quantitative PCR technology.
\end{abstract}

Results: Methylation status for PTEN and SMAD4 were statistically significant as breast cancer patients reported hypermethylation compared to benign and control groups (77.1 \pm 17.9 vs. $24.9 \pm 4.5$ and $15.1 \pm 1.4$ and $70.1 \pm 14.4$ vs. $28.2 \pm 0.61$ and $29.5 \pm 3.6$, respectively). ROC curve analysis revealed that both PTEN (AUC $=0.992$ ) and SMAD4 ( $A \cup C=0.853$ ) had good discriminative power for differentiating BC from all non-cancer individuals (benign and healthy combined) compared to routine tumor markers CEA (AUC $=0.538$ ) and CA15.3 (AUC =0.686). High PTEN methylation degree was associated with late stages (84.2 \pm 17.4$)$, positive lymph node (84.2 \pm 18.5$)$, positive ER (81.3 \pm 19.7), positive PgR (79.5 \pm 19.1), and positive HER2 (80.7 \pm 19.0$)$ vs. $67.4 \pm 13.8,70.6 \pm 14.8,72.8 \pm 14.9,72.5$ \pm 14.7 , and $70.2 \pm 13.5$ in early stages, negative lymph node, negative ER, negative PgR, and negative HER2, respectively. Similar results were obtained regarding SMAD4 methylation. Sensitivity, specificity, positive and negative predictive values, and accuracy for methylated PTEN were 100\%,95\%,99.1\%, 100\%, and 95\%, respectively when differentiated BC from all-non cancer controls. Interestingly, PTEN could distinguish early BC stages with good sensitivity $84.4 \%, 51.4 \%, 69.1 \%, 72 \%$, and $70 \%$, respectively.

Conclusion: Methylation status of PTEN and SMAD4 is a promising blood marker for early detection of breast cancer. Future studies are needed for their role as prognostic markers.

Keywords: Breast cancer, DNA methylation, Circulating molecular marker, Diagnosis

\section{Background}

Breast cancer (BC) is the most widely neoplasm in women [1] that progresses silently, leading to neighboring metastasis and poor prognosis. Moreover classification of breast cancer into relevant molecular subtypes (luminal A, luminal B, triple-negative/basal-like, HER2enriched, and normal-like breast cancer) is important in treatment strategy and hence their prognosis [2]. The

\footnotetext{
* Correspondence: Shimaaelmenawy@yahoo.com

${ }^{2}$ Chemistry Department, Faculty of Science, Damietta University, Damietta 34517, Egypt

Full list of author information is available at the end of the article
}

survival rate improves with early diagnosis [3]. Numerous hazard factors such as family history, gene mutations, sex, aging, estrogen, and unhealthy lifestyle could increase $\mathrm{BC}$ probability [4]. The most $\mathrm{BC}$ widely recognized symptom is a new mass or lump [5] that has been diagnosed by many methods such as screening tests (physical tests and mammogram), lab tests (tumor markers as CEA and CA15.3), and breast biops y[6]. However, these screening methods have limitations such as radiation exposure and maybe affected by breast density [7]. Moreover, no effective blood-based marker is

\section{Springer Open}

(c) The Author(s). 2021 Open Access This article is licensed under a Creative Commons Attribution 4.0 International License, which permits use, sharing, adaptation, distribution and reproduction in any medium or format, as long as you give appropriate credit to the original author(s) and the source, provide a link to the Creative Commons licence, and indicate if changes were made. The images or other third party material in this article are included in the article's Creative Commons licence, unless indicated otherwise in a credit line to the material. If material is not included in the article's Creative Commons licence and your intended use is not permitted by statutory regulation or exceeds the permitted use, you will need to obtain permission directly from the copyright holder. To view a copy of this licence, visit http://creativecommons.org/licenses/by/4.0/. 
available for $\mathrm{BC}$ detection, particularly for patients with early-stage and low-grade tumor [7].

Epigenetic mutations, involved DNA methylation, were responsible for the control of gene expression by regulating gene transcription [8]. Most DNA methylation is catalyze by DNA methyltransferases and exhibits essential physiological role in numerous key functions of cells [9]. Aberrant promoter methylation of numerous tumor suppressor genes was obtained in $\mathrm{BC}$ initiator lesions, representing that DNA methylation is an early event in breast carcinogenesis [10].

Among these tumor suppressor genes, tensin homolog (PTEN) gene and its function loss affects the increased levels of tumor aneuploidy that is one of the most projecting features of human cancers [11]. PTEN gene is reported to be mutated in a number of human malignancies including prostate [12], cervical [13], and BCs [14]. Former studies have shown an association of PTEN promoter methylation with its diminished expression in $\mathrm{BC}$ [15] which may indicate its role in breast carcinogenesis [16]. In a previous study [17], it was reported that transforming growth factor $\beta$ (TGF- $\beta$ ) facilitates PTEN suppression in pancreatic cancer cell. Another tumor suppressor gene is SMAD4 which shows critical role in the TGF- $\beta$ signaling pathway as well. TGF- $\beta$ acts as significant characters in various biological procedures, such as apoptosis, in addition to cancer initiation and progression $[18,19]$. Mutation and promoter hypermethylation of SMAD4 has been reported in numerous human cancers [20].

Thus, the two suppressor genes PTEN and SMAD4 are linked through TGF- $\beta$ pathway as they can mediate carcinogenesis [21], and their loss may attributes to cancer aggressiveness [22]. Hence, this study aimed to investigate methylation patterns of both PTEN and SMAD4 among primary BC patients and compare their role with other non-cancer groups as well as assess their diagnostic effectiveness with other tumor markers (CEA and CA15.3). Also, we aimed to evaluate the association between these patterns and clinicopathological features.

\section{Methods}

\section{Patients and specimen collection}

A total of 110 patients were involved; they were enrolled from Surgical Department, Oncology Centre, Egypt. They were divided according to their clinical diagnosis into primary $\mathrm{BC}$ group $(n=80,72.7 \%)$ and benign breast diseases $(n=30,27.2 \%)$. BC patients fulfilled the inclusion criteria as being diagnosed with primary $\mathrm{BC}$ patients before receiving any treatment or underwent surgical resection and have not any other tumors. Demographic and clinico-pathological data for enrolled individuals were collected from their medical reports. $\mathrm{BC}$ patients were diagnosed according to their staging and grading systems following the TNM classification [23]. In addition, 30 healthy individuals were included and they served as control group. Blood samples $(3 \mathrm{~mL})$ were withdrawn from all participants in tubes EDTA and centrifuged at $4000 \mathrm{rpm}$ for $5 \mathrm{~min}$. at $4{ }^{\circ} \mathrm{C}$ for further processing to detect the investigated markers.

\section{Hormonal receptor status analysis and molecular subtype of $\mathrm{BC}$}

For each sample, the expression of hormonal receptors and $\mathrm{BC}$ molecular subtype was identified by immunohistochemistry (IHC) method using formalin-fixed paraffinembedded tissue. IHC staining was evaluated. Both ER and PgR were consider positive if $\geq 10 \%$ nuclei was positively stained using ten high-power field, and HER-2neu was considered positive if scored as +3 .

\section{Tumor markers assessment}

By enzyme-linked immunosorbent assay (ELISA), both CEA and CA15.3 were determined in serum samples using available commercial kits (Immuno-speccorporation, the Netherlands) based on instructions in the manual manufacturer's protocol. Their levels were detected using GloMax-Multi detection system (Promega, USA).

\section{DNA extraction}

DNA was extracted using QIAamp DNA Min kit (Qiagen, Hilden, Germany), according to the manufacturers' recommendations, which based on spin column for DNA extraction method. The purity and the concentration of the extracted DNA were detected before further investigation using nano-drop spectrophotometer (Quawell, Q-500, Scribner, USA) then stored at $-20{ }^{\circ} \mathrm{C}$ till further restriction digestion.

\section{Detection of DNA methylation pattern}

DNA methylation pattern was detected using EpiTect Methyl II quantitative polymerase chain reaction (qPCR) System (Qiagen, Germany). This technique is based on the detection of remaining input genome after digestion with a methylation-sensitive restriction enzyme. This technique requires 2 phases: phase I, digestion of DNA samples which was carried out following the manufacturer instruction of EpiTect Methyl II DNA Restriction Kit. Briefly, it was as follows: the input genomic DNA was aliquoted into four equal portions and subjected to four tubes mock (M0), methylation-sensitive (Ms), methylation-dependent (Md), and methylation-sensitivedependent enzyme (Msd). All 4 reactions were incubated at $37^{\circ} \mathrm{C}$ for $6 \mathrm{~h}$ then at $65^{\circ} \mathrm{C}$ for $20 \mathrm{~min}$ using thermal cycler (SureCycler 8800, Agilent, Santa Clara, CA, USA). Then, phase II is as follows: qPCR for methylation status (using Max3005P QPCR system; Stratagene, Agilent Technologies, CA, USA), the enzyme reactions were 
mixed directly with qPCR master mix $\left(\mathrm{RT}^{2}\right.$ qPCR SYBR Green/ROX Master Mix, Cat number 330520) and were dispensed into a PCR plate containing pre-aliquoted primer mixes (EpiTect Methyl II qPCR Primer Assay). Real-time PCR is carried out using specified cycling conditions, $95^{\circ} \mathrm{C}$ for $10 \mathrm{~min}$ ( 1 cycle), then $99^{\circ} \mathrm{C}$ for $30 \mathrm{~s}$ and $72^{\circ} \mathrm{C}$ for $1 \mathrm{~min}$ ( 3 cycles), and finally $97^{\circ} \mathrm{C}$ for $15 \mathrm{~s}$ and $72^{\circ} \mathrm{C}$ for $1 \mathrm{~min}$ ( 40 cycles). Finally, the raw $\Delta \mathrm{CT}$ values were pasted into the data analysis spreadsheet (EpiTect Methyl II PCR Array Microsoft Excel based data analysis template), which automatically calculates the relative amount of methylated and unmethylated DNA fractions.

\section{Data analyses}

Data were analyzed using SPSS (SPSS, Inc., Chicago, USA; version 20) and GraphPad prism (version 6). Significant difference between groups was determined using (ANOVA) for normally distributed values and Kruskal-
Wallis for non-normal distributed variables and Fisher's LSD as post-hoc test and $P$ value were two-tailed and considered significant if $<0.05$. Receiver operating characteristic (ROC) curve was constructed among studied groups to identify the specificities and sensitivities for investigated genes. Person correlation coefficient $(r)$ was utilized for determining the association between target gene methylation degree and other parameters.

\section{Results}

\section{Patients characteristic}

Patients demographic and clinicopathological data were summarized in Table 1 . Both benign and healthy controls were age matched $(P=0.923)$ with $\mathrm{BC}$ patients. Most of $\mathrm{BC}$ patients $(56.2 \%)$ and patients with benign breast disease (56.7\%) were premenopausal. For benign breast lesion, they were pathologically divided into 12 with follicular hyperplasia, 10 with intraductal papillomatosis, and 8 with fibrocystic changes. According to

Table 1 Demographic and clinicopathological data of breast carcinoma patients

\begin{tabular}{|c|c|c|c|c|}
\hline Parameter & Breast cancer & Benign & Healthy & $P$ value \\
\hline Number & 80 & 30 & 20 & - \\
\hline Age (years, mean $\pm S D$ ) & $52.4 \pm 9.1$ & $52.0 \pm 9.3$ & $51.5 \pm 8.9$ & $0.923^{\mathrm{a}}$ \\
\hline \multicolumn{5}{|c|}{ Menopause, number (percentage) } \\
\hline Post-menopausal & $35(43.8 \%)$ & $13(43.3 \%)$ & $8(40 \%)$ & \multirow[t]{2}{*}{$0.955^{b}$} \\
\hline Pre-menopausal & $45(56.2 \%)$ & $17(56.7 \%)$ & $12(60 \%)$ & \\
\hline \multicolumn{5}{|c|}{ Tumor invasion number (percentage) } \\
\hline In situ & $32(40 \%)$ & - & - & - \\
\hline Invasive & $48(60 \%)$ & - & - & - \\
\hline \multicolumn{5}{|l|}{ Tumor depth (stage) } \\
\hline Early $(T \leq 2)$ & $35(43.8 \%)$ & - & - & - \\
\hline Late $(T>2)$ & $45(56.2 \%)$ & - & - & - \\
\hline \multicolumn{5}{|l|}{ Tumor grade } \\
\hline Low (G1) & $30(37.5 \%)$ & - & - & - \\
\hline High (G2-3) & $50(62.5 \%)$ & - & - & - \\
\hline \multicolumn{5}{|l|}{ Lymph node invasion } \\
\hline Negative & $42(52.5 \%)$ & - & - & - \\
\hline Positive & $38(47.5 \%)$ & - & - & - \\
\hline \multicolumn{5}{|l|}{ Estrogen receptor (ER) } \\
\hline Negative & $40(50 \%)$ & - & - & - \\
\hline Positive & $40(50 \%)$ & - & - & - \\
\hline \multicolumn{5}{|c|}{ Progesterone receptor (PgR) } \\
\hline Negative & $28(35 \%)$ & - & - & - \\
\hline Positive & $52(65 \%)$ & - & - & - \\
\hline \multicolumn{5}{|l|}{ HER-2/neu status } \\
\hline Negative & $28(35 \%)$ & - & - & - \\
\hline Positive & $52(65 \%)$ & - & - & - \\
\hline
\end{tabular}

*Statistical analysis was carried out by (a) ANOVA test and (b) chi-squared $\left(X^{2}\right)$ test in case of dichotomized values $P>0.05$ is considered non-significant; $P \leq 0.05$ is considered significant 
the hormonal receptor status, $\mathrm{BC}$ patients were classified into luminal A (ER/PR $\left.{ }^{+}, \mathrm{HER} 2^{-} ; 8 / 80(10 \%)\right)$, luminal B $\left(\mathrm{ER} / \mathrm{PR}^{+}, \mathrm{HER} 2^{+} ; 52 / 80(65 \%)\right)$, and triple negative $\left(\mathrm{ER}^{-} /\right.$ $\left.\mathrm{PR}^{-} / \mathrm{HER}^{-} ; 20 / 80(25 \%)\right)$.

DNA methylation status and tumor markers level among investigated groups

$\mathrm{BC}$ patients were associated with high methylation degree of PTEN and SMAD4. In contrast to CEA (Fig. 1a) and CA15.3 (Fig. 1b), BC patients were associated with high methylation degree of PTEN (77.1 \pm 17.9 vs. $24.9 \pm$ 4.5 for benign and $15.1 \pm 1.4$ for healthy individuals; Fig. 1c) and SMAD4 (70.1 \pm 14.4 vs. $28.2 \pm 0.61$ for benign and $29.5 \pm 3.6$ for healthy individuals; Fig. 1d). To evaluate the diagnostic efficacy for investigated items, ROC curves (Fig. 2a-d) were plotted. Despite CEA (AUC = 0.538 ) and CA15.3 (AUC $=0.686$ ), ROC curve analysis revealed that both PTEN $($ AUC $=0.992)$ and SMAD4 (AUC $=0.853$ ) had extremely discriminative power for good differentiating $\mathrm{BC}$ from all non-cancer individuals (benign and healthy combined).

\section{PTEN and SMAD4 high methylation pattern and clinicopathological features}

No significant result was reported between methylation of PTEN and SMAD4 with either age or menopausal status as shown in Table 2. High PTEN methylation degree was significantly associated with tumor late stage
(84.2 \pm 17.4 vs. $67.4 \pm 13.8$ ), positive lymph node metastasis $(84.2 \pm 18.5$ vs. $70.6 \pm 14.8)$, positive ER (81.3 \pm 19.7 vs. $70.6 \pm 14.8)$, positive PR (79.5 \pm 19.1 vs. $72.5 \pm$ $14.7)$, and positive HER2 $(80.7 \pm 19.0$ vs. $70.2 \pm 13.5)$ as shown in Fig. 3a-f. Similarly, high SMAD4 methylation degree was significantly associated $(P<0.05)$ with high grade $(74 \pm 14.4$ vs. $63.3 \pm 12.01)$, tumor late stage $(84.2$ \pm 17.4 vs. $64.5 \pm 12.7$ ), positive lymph node metastasis $(75.1 \pm 14.1$ vs. $65.6 \pm 13.4)$, positive ER (72 \pm 15.5 vs. $68.2 \pm 13.2)$, positive PR $(72.8 \pm 14.5$ vs. $65.2 \pm 13.3)$, and positive HER2 $(72.3 \pm 14.6$ vs. $66 \pm 13.4)$ as shown in Fig. $4 \mathrm{a}-\mathrm{f}$. Moreover, as shown in Table 2, both methylated PTEN and SMAD4 genes were significantly $(P<$ $0.05)$ correlated with CA15.3, tumor stage, grade, and lymph node involvement. Moreover, PTEN methylation was significantly related with breast cancer subtypes. High significant correlation was detected between PTEN and SMAD4 methylation $(r=0.727, P=0.0001)$.

\section{Diagnostic performance of PTEN and SMAD4 methylation degree}

As reported in Table 3, methylated PTEN and SMAD4 genes were superior to CEA and CA15.3 in early BC detection. Also, their diagnostic ability was better than other tumor marker in differentiated early stages and low-grade breast cancer; however, the sensitivity of CEA was more than that of SMAD4 in detection of low-grade tumors (Table 3).

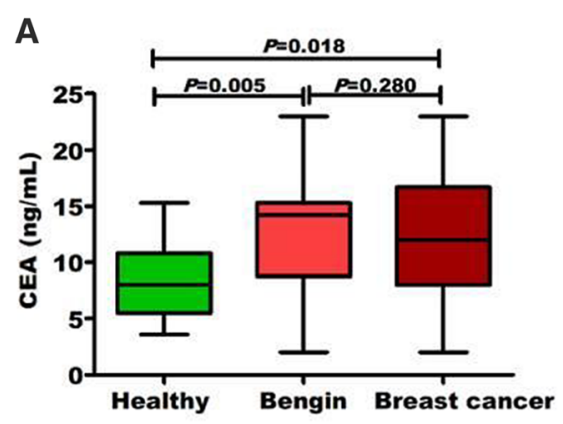

B
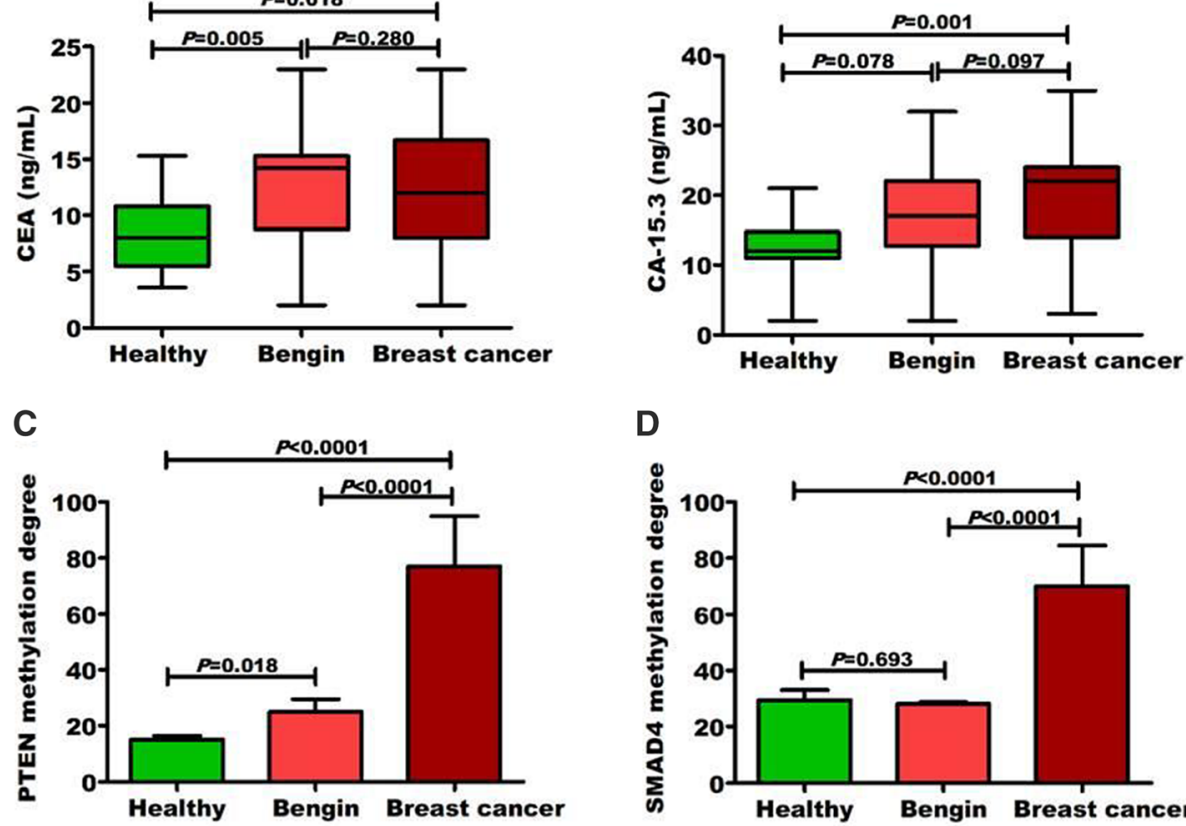

D

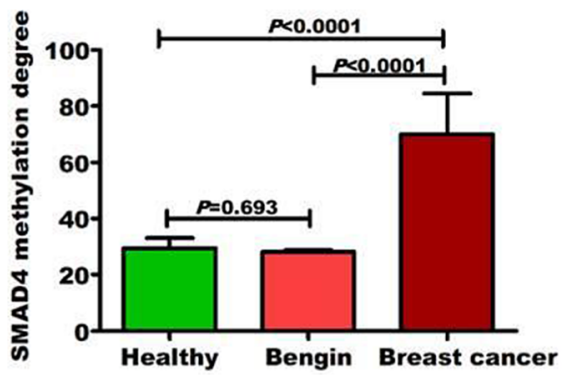

Fig. 1 The distribution of investigated markers among the investigated groups. a Level of CEA, (b) level of CA 15.3, (c) level of PTEN, and (d) level of SMAD4 
A

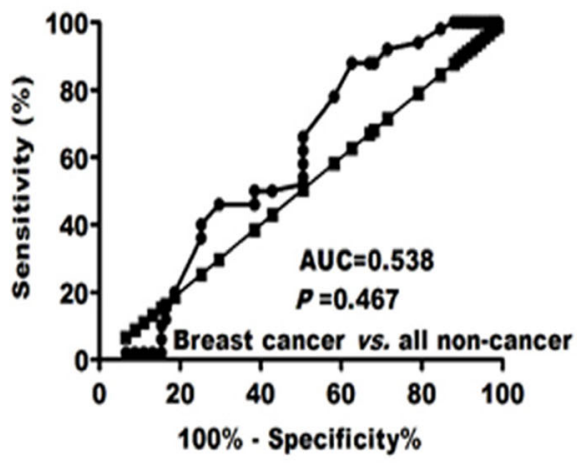

C

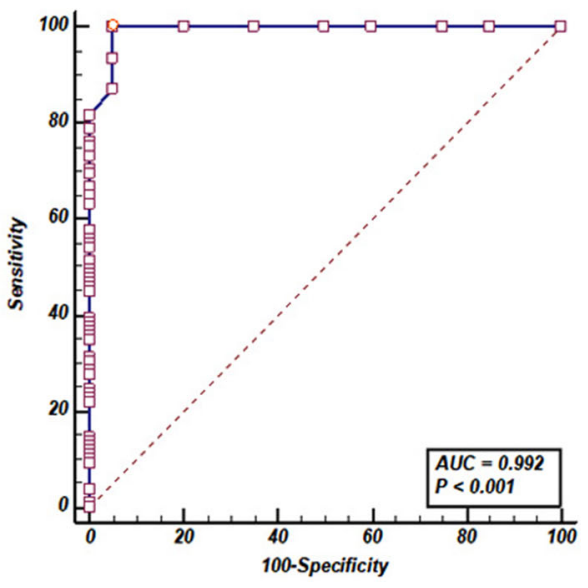

B

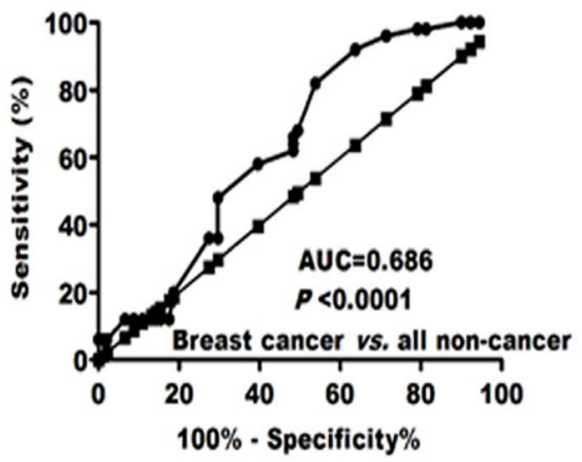

D

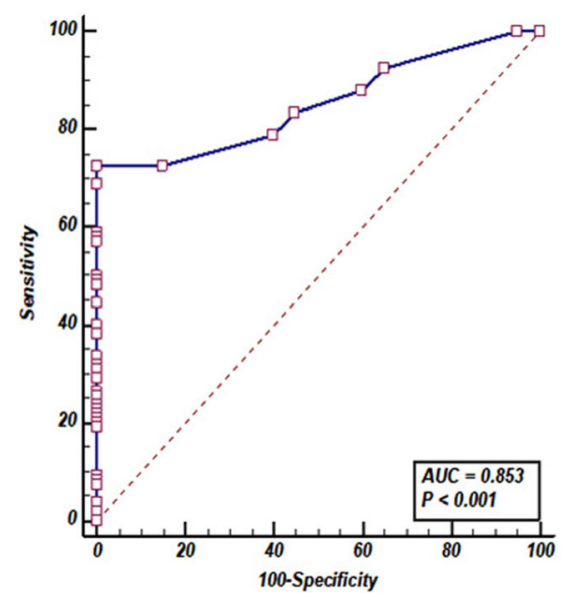

Fig. 2 Receiver operating characteristic curve for (a) CEA, (b) CA15.3, (c) methylated PTEN, and $\mathbf{d}$ methylated SMAD4 to distinguish patients with breast cancer from non-cancer (healthy and benign combined)

Table 2 Correlation between methylated PTEN and SMAD4 with other parameters

\begin{tabular}{lllll}
\hline Factors & PTEN methylation status & & \multicolumn{2}{l}{ SMAD4 methylation status } \\
\cline { 2 - 3 } & $\boldsymbol{R}$ & $\boldsymbol{P}$ value & -0.017 & $\boldsymbol{P}$ value \\
\hline Age & -0.09 & 0.315 & -0.016 & 0.844 \\
Menopause & -0.1 & 0.270 & 0.086 & 0.861 \\
CEA & 0.209 & 0.017 & 0.265 & 0.329 \\
CA15-3 & 0.395 & 0.0001 & 0.320 & 0.002 \\
Tumor stage & 0.507 & 0.0001 & 0.329 & 0.004 \\
Tumor grade & 0.492 & 0.0001 & 0.323 & 0.003 \\
Lymph node & 0.454 & 0.0001 & 0.120 & 0.004 \\
ER & 0.203 & 0.07 & 0.237 & 0.289 \\
PgR & 0.315 & 0.004 & 0.194 & 0.034 \\
HER2 & 0.042 & 0.711 & 0,154 & 0.084 \\
Molecular subtypes & 0.321 & 0,0001 & & 0.175 \\
Methylated SMAD4 & 0.727 & 0.0001 &
\end{tabular}

*Correlations were determined according to Pearson coefficient; $P<0.05$ was significant 

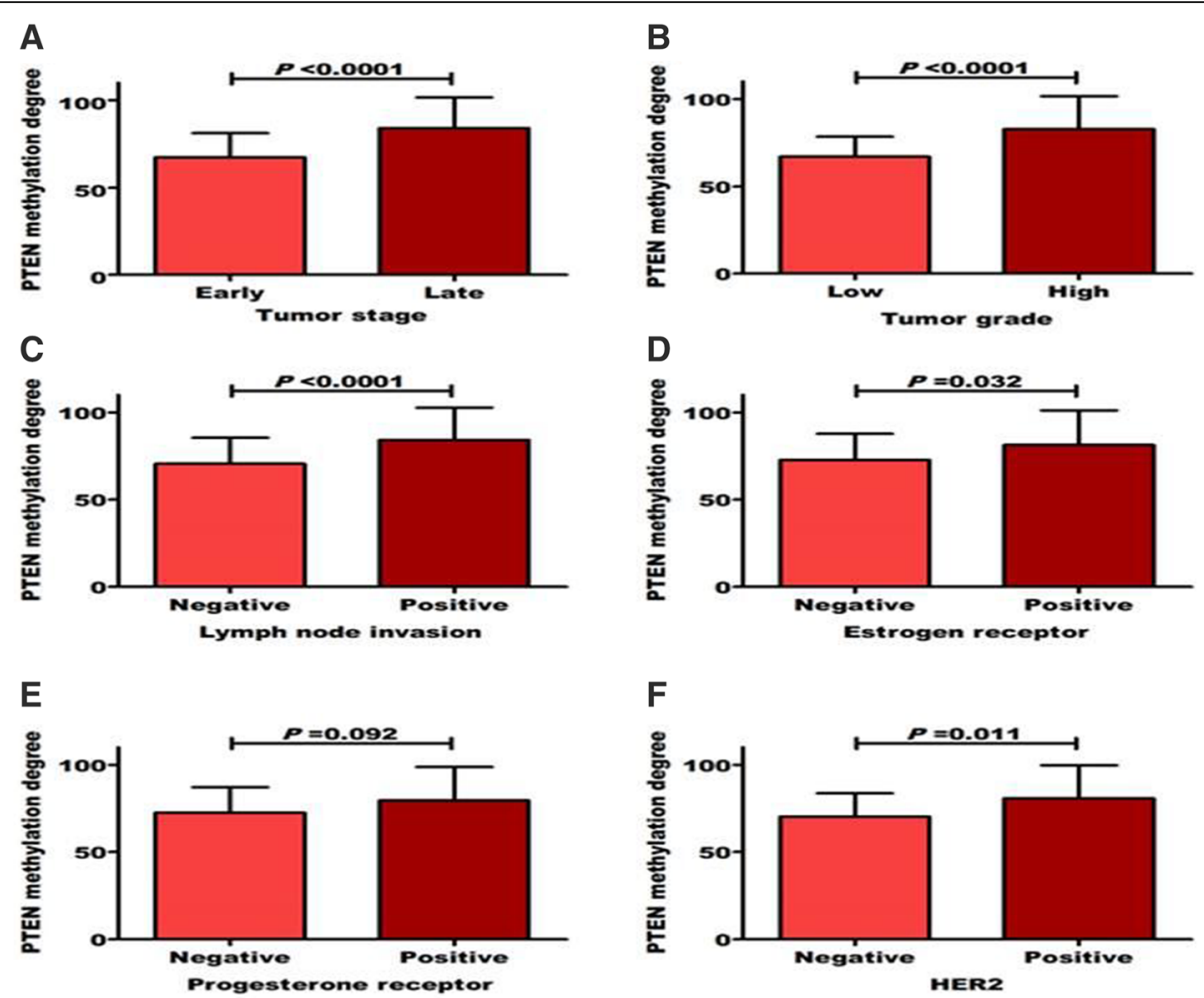

Fig. 3 Distribution of PTEN methylation degree among breast cancer patients according to tumor (a) stages, (b) grades, (c) lymph node, (d) estrogen receptor, (e) progesterone receptor, and (f) HER2 statuses. Significant difference was determined using Student's $t$ test. $P$ value $<0.05$ was considered significant

\section{Discussion}

$\mathrm{BC}$ is the most frequently occurring in women worldwide and the second most prevalent cancer [24]. Also, it is the most common tumor affecting Egyptian females [25]. Early-stage cancer detection may minimize death rates for BC. There are multiple diagnostic methods for breast tumor detection; however, because of the weakness of these approaches, researchers have used distinctive biomarkers as alternatives to detect BC [26]. Carcinogenesis arises from significant modifications in DNA methylation within the cell. These alterations are distinguished by the hypomethylation or hypermethylation of multiple 5'-cytosine-phosphate-guanine-3' (CpG) islands [27]. So, the aim of this study was to evaluate whether the methylation pattern of both SMAD4 and PTEN genes was correlated with clinical variables of breast carcinoma.

Both SMAD4 and PTEN have been revealed a closely linked in the regulation of tumor infiltration and distant metastasis. For instance, there were findings suggest that the loss of Smad4 and PTEN may lead to more aggressive disease and poor prognosis in patients with colorectal adenocarcinoma compared to the loss of SMAD4 or PTEN alone [28], pancreatic cancer [29], lung cancer [30], and invasive intestinal-type gastric cancer [22].
PTEN is a tumor suppressor gene; promoter methylation of PTEN is implicated in various types of cancer including non-small-cell lung carcinoma [31], gastric [32], cervical cancer [13, 33], and endometrial carcinoma [34], including $\mathrm{BC}[14,15,35]$. Promoter hypermethylation of the PTEN gene is a key event in the progression of $\mathrm{BC}$ [36]. In the current study, it was observed that there were no correlations between age of individuals and methylation degree of PTEN $(P=0.315)$; this result was in harmony with the study by [16] Alam et al., and it was in dissimilarity with a study of Kazim et al. [37], who revealed a significant difference with north Indian breast cancer patient's age. In study by Wu et al. [35], who used MSP technology, only a few of CpG islands in the promoter region of genes were stately. This study noticed that hypermethylation of PTEN was significantly associated with menopausal status $(P=0.027)$; this is in disagreement with current results that investigated nonsignificant difference with menopause status $(P=0.238)$; variability in results could be due to the size of study groups, as well as applied methodology. For example, Kazim et al. used another method (methylation-specific PCR) on another race (Asian populations) [37].

Methylated PTEN status reported a significant correlation with tumor markers, tumor stage, and tumor 

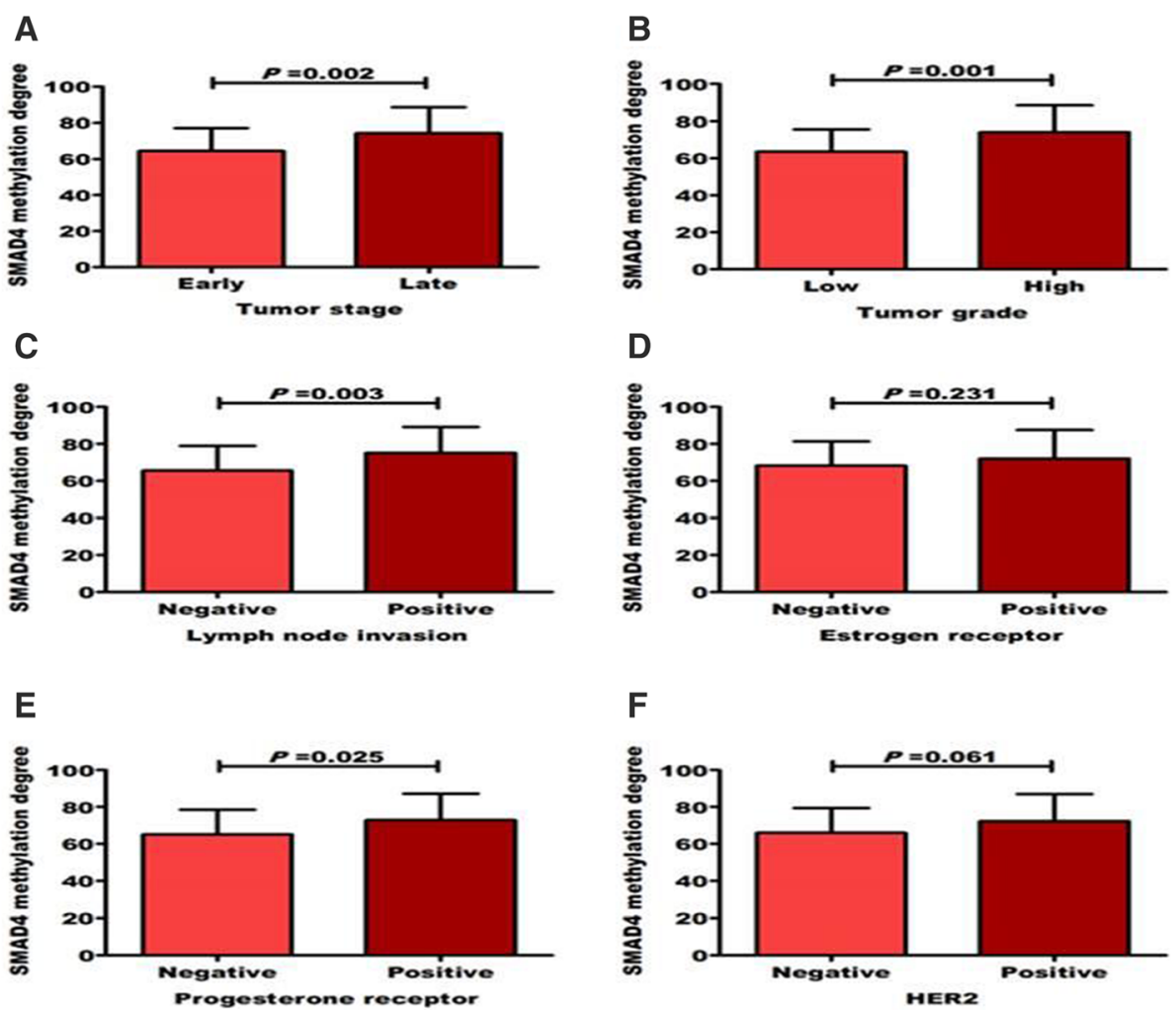

Fig. 4 Distribution of SMAD4 methylation degree among breast cancer patients according to tumor (a) stages, (b) grades, (c) lymph node, (d) estrogen receptor, e progesterone receptor, and (f) HER2 statuses. Significant difference was determined using Student's $t$ test. $P$ value $<0.05$ was considered significant

Table 3 Overall sensitivity, specificity, PPV, NPV, and accuracy of investigated methylated genes and tumor markers

\begin{tabular}{lccccc}
\hline Variables & Sen.\% & Spe. \% & PNV\% & NPV\% & Acc.\% \\
\hline \multicolumn{7}{l}{ Early detection of breast cancer vs. all non-cancer } \\
CEA $(\mathrm{ng} / \mathrm{ml})$ & 70 & 40 & 65.1 & 45.5 & 58.5 \\
CA15.3 $(\mathrm{ng} / \mathrm{ml})$ & 75 & 48 & 69.8 & 54.5 & 64.6 \\
PTEN & 100 & 94 & 96.4 & 100 & 97.7 \\
SMAD4 & 100 & 100 & 100 & 100 & 100
\end{tabular}

Early stage breast cancer vs. all non-cancer

$\begin{array}{llllll}\text { CEA }(\mathrm{ng} / \mathrm{ml}) & 51.1 & 51.4 & 57.5 & 45 & 51.3 \\ \text { CA15.3 }(\mathrm{ng} / \mathrm{ml}) & 51.1 & 51.4 & 57.5 & 45 & 51.3 \\ \text { PTEN } & 84.4 & 51.4 & 69.1 & 72 & 70 \\ \text { SMAD4 } & 66.7 & 40 & 58.8 & 48.3 & 55\end{array}$

Low-grade breast cancer vs. all non-cancer

\begin{tabular}{llllll} 
CEA $(\mathrm{ng} / \mathrm{ml})$ & 66 & 60 & 73 & 51.4 & 66 \\
CA15.3 $(\mathrm{ng} / \mathrm{ml})$ & 54 & 50 & 54 & 50 & 54 \\
PTEN & 80 & 70 & 80 & 70 & 80 \\
SMAD4 & 60 & 60 & 60 & 60 & 60 \\
\hline
\end{tabular}

grade; also, there was a significant correlation between methylated PTEN and PR $(P=0.004)$. This in agreement with the study of Alam et al. [16], as there was significant correlation noticed among PTEN methylation and tumor grade and tumor stage. These findings were in consistent with previously reported studies such as Yari [36] and Zhang et al. [14], as they indicated no association between methylated PTEN with other pathological characteristics of patients. This difference in results may be due to genetic predisposition. Further study is in progress to investigate the relation between PTEN and clinical characteristics on a large cohort of Egyptian patients. Breast cancer can be divided into four molecular subtypes that differ in their response as previously reported [2]. In the current study, a significant relation was reported between PTEN and molecular subtypes of breast cancer which reveal the impact for detection of methylation status for further treatment strategy [38].

SMAD4 is a tumor suppressor gene that regulates cell proliferation, distinction, and extracellular matrix production [39]. It has been reported that SMAD4 acts as a prognostic biomarker in various human malignancies such as colorectal carcinoma [40] and pancreatic carcinoma [41], but its role as a prognostic marker in breast carcinoma is still unclear [42]. Deckers et al. [43] 
informed that SMAD4/TGF- $\beta$-induced growth protection and apoptosis only happened at early stages of BC. However, Li et al. [44] noticed that SMAD4 stimulated apoptosis in estrogen receptor- $\alpha(E R \alpha)$-positive BC cells.

In a few cancer types, promoter hypermethylation of the SMAD4 gene has been recorded but does not appear to be a common event in carcinogenesis [20]. In contrast, hypermethylation was not determined in colorectal malignancies and small intestinal neuroendocrine cancers [45-47]. In the current study, methylation SMAD4 pattern was significantly correlated with CA15.3, tumor stage and grade, and lymph node. These investigations about methylation status of SMAD4 in our study were the first study reporting implication of the methylated SMAD4 in Egyptian breast cancer patients.

Moreover, a significant correlation was reported between methylation status of both PTEN and SMAD4 ( $P$ $=0.0001)$, and this could be attributed that both are tumor suppressor genes related to TGF- $\beta$ pathway [17, 22]. In this study, methylation of SMAD4 can distinguish breast cancer patients from healthy and benign individuals, where methylation degree of SMAD4 in breast cancer is higher than methylation in benign and healthy controls. Methylated SMAD4 pattern may be a good power for early detection of $\mathrm{BC}$ and even when considering the high-risk $\mathrm{BC}$ group. This in disagreement with several studies that revealed that hypermethylation was not found in colorectal malignancies and small intestinal neuroendocrine tumors [45-47], but our results were in agreement with study by Onwuegbusi et al. who reported that $70 \%$ of esophageal carcinoma cases were found to be hypermethylated at SMAD4 promoter [48].

\section{Conclusions}

In conclusion, to our knowledge, this is the first study to focus on the diagnostic efficacy of the methylation pattern for both SMAD4 and PTEN in BC and to assess their correlation with each other as two important tumor suppressor genes related to certain pathways (TGF- $\beta$, tyrosine kinase). Moreover, their superiority in detection of $\mathrm{BC}$ over routine classical tumor markers (CEA and CA15.3) as serum-based marker maybe directed to a better diagnostic marker for BC. Hence, a further study on large cohort samples is recommended.

\section{Abbreviations}

BC: Breast cancer; PTEN: Phosphatase and tensin homolog; TGF- $\beta$ : $\beta$ tumor growth factor; qPCR: Quantitative polymerase chain reaction

\section{Acknowledgements}

The authors would like to thank the Surgery and Pathology Departments, Mansoura University, for providing the blood samples and their pathological reports for the enrolled individuals.

\section{Authors' contributions}

MMS designed the experiments and performed all the experiments. EAS and CAM suggested appropriate modifications and made corrections. SS is responsible for the statistical analysis. $A D$ and $A A$ analyzed the pathological data. All authors read and approved the final manuscript.

Funding

No funding was obtained for this study.

Availability of data and materials

Data is not available due to [ethical/legal/commercial] restrictions: Due to the nature of this research, participants of this study did not agree for their data to be shared publicly, so supporting data is not available.

\section{Declarations}

Ethics approval and consent to participate

The study protocol was accepted by the Medical Ethical Committee National Research Centre with the code of (ID: 15170). Informed written consents were obtained from all patients and controls.

Consent for publication

Not applicable.

\section{Competing interests}

The authors report no conflicts of interest in this work.

\section{Author details}

${ }^{1}$ Biochemistry Department, Genetic Engineering and Biotechnology Research Division, High Throughput Molecular and Genetic Laboratory, Center for Excellences for Advanced Sciences, National Research Centre, Dokki, Giza, Egypt. ${ }^{2}$ Chemistry Department, Faculty of Science, Damietta University, Damietta 34517, Egypt. 3Surgical Oncology Department, Mansoura Oncology Centre, Faculty of Medicine, Mansoura University, Mansoura, Egypt.

Received: 21 December 2020 Accepted: 26 March 2021

Published online: 06 April 2021

\section{References}

1. Salta S, Nunes SP, Sousa MF, Lopes P, Freitas M, Caldas M, Antunes L, Castro $F$, Antunes $p$ et al (2018) A DNA methylation-based test for breast cancer detection in circulating cell-free DNA. J Clin Med 7(11):420. https://doi.org/1 $0.3390 / \mathrm{jcm} 7110420$

2. Al-thoubaity FK (2020) Molecular classification of breast cancer: a retrospective cohort study. Ann Med Surg 49:44-48. https://doi.org/10.1016/ j.amsu.2019.11.021

3. Mahvi DA, Liu R, Grinstaff MW, Colson YL, Raut CP (2018) Local cancer recurrence: the realities, challenges, and opportunities for new therapies. CA Cancer J Clin 68(6):488-505. https://doi.org/10.3322/caac.21498

4. Rodgers KM, Udesky JO, Rudel RA, Brody JG (2018) Environmental chemicals and breast cancer: an updated review of epidemiological literature informed by biological mechanisms. Environ Res 160:152-182. https://doi. org/10.1016/j.envres.2017.08.045

5. Breast Cancer Treatment (PDQ ${ }^{\oplus}(2014)$ Archived from the original on 5 July 2014. Retrieved 29 June 2014.

6. Corsetti V, Houssami N, Ghirardi M, Ferrari A, Speziani M, Bellarosa S, Remida G, Gasparotti C, Galligioni E, Ciatto S (2011) Evidence of the effect of adjunct ultrasound screening in women with mammography-negative dense breasts: interval breast cancers at 1 year follow-up. Eur J Cancer 47(7): 1021-1026. https://doi.org/10.1016/j.ejca.2010.12.002

7. Attallah AM, El-Far M, Omran MM, Abdallah SO, El-Desouky MA, El-Dosoky I, Abdelrazek MA, Attallah AA, Elweresh MA et al (2014) Circulating levels and clinical implications of epithelial membrane antigen and cytokeratin-1 in women with breast cancer: can their ratio improve the results? Tumour Biol 35(11):10737-10745. https://doi.org/10.1007/s13277-014-2375-1

8. Uramova S, Kubatka P, Dankova Z, Kapinova A, Zolakova B, Samec M, Zubor P, Zulli A, Valentova V, Kwon TK, Solar P, Kello M, Kajo K, Busselberg D, Pec M, Danko J (2018) Plant natural modulators in breast cancer prevention: status quo and future perspectives reinforced by predictive, preventive, and personalized medical approach. EPMA J 9(4):403-419. https://doi.org/10.1 007/s13167-018-0154-6

9. Zeng Y, Chen T (2019) DNA methylation reprogramming during mammalian development. Genes 10:257 
10. Van Hoesel AQ, Sato Y, Elashoff DA, Turner RR, Giuliano AE, Shamonki JM, Kuppen PJ, van de Velde CJ, Hoon DS (2013) Assessment of DNA methylation status in early stages of breast cancer development. $\mathrm{Br} \mathrm{J}$ Cancer 108(10):2033-2038. https://doi.org/10.1038/bjc.2013.136

11. Vidotto T, Tiezzi DN, Squire JA (2018) Distinct subtypes of genomic PT EN deletion size influence the landscape of aneuploidy and outcome in prostate cancer. Mol Cytogenet 11(1):1. https://doi.org/10.1186/s13039-0170348-y

12. Reid AHM, Attard G, Ambroisine L, Fisher G, Kovacs G, Brewer D, Clark J, Flohr P, Edwards S, Berney DM, Foster CS, Fletcher A, Gerald WL, Møller $\mathrm{H}$ et al (2010) Molecular characterisation of ERG, ETV1 and PTEN gene loci identifies patients at lowand high risk of death from prostate cancer. Br J Cancer 102(4):678-684. https://doi.org/10.1038/sj. bjc.6605554

13. Rizvi MMA, Alam MS, Ali A, Mehdi SJ, Batra S, Mandal AK (2011) Abrrant promoter methylation and inactivation of PTEN gene in cervical carcinoma from Indian population. J Cancer Res Clin Oncol 137(8):1255-1262. https:// doi.org/10.1007/s00432-011-0994-0

14. Zhang HY, Liang F, Jia ZL, Song ST, Jiang ZF (2013) PTEN mutation, methylation and expression in breast cancer patients. Oncol Lett 6(1):161168

15. Lu YM, Cheng F, Teng LS (2016) The association between phosphatase and tensin homologhypermethylation and patients with breast cancer, a metaanalysis and literature review. Sci Rep 6(1):32723. https://doi.org/10.1038/ srep32723

16. Alam MS, Jerah ABA, Ashraf AM, Kumaresan K, Eisa ZM, Mikhail NT (2017) Promoter methylation and loss of expression of PTEN gene in breast cancer patients from Saudi population. J Clin Exp Oncol 6:6

17. Chow JYC, Dong H, Quach KT, Van Nguyen PN, Chen K, Carethers JM (2008) TGF- $\beta$ mediates PTEN suppression and cell motility through calciumdependent PKC-a activation in pancreatic cancer cells. Am J Physiol Gastrointest Liver Physiol 294(4):899-905

18. Zhao M, Mishra L, Deng CX (2018) The role of TGF- $\beta / S M A D 4$ signaling in cancer. Int J Biol Sci 14(2):111-123. https://doi.org/10.7150/ijbs.23230

19. Ullah I, Sun W, Tang L, Feng J (2018) Roles of Smads family and alternative splicing variants of Smad4 in different cancers. J Cancer 9(21):4018-4028. https://doi.org/10.7150/jca.20906

20. Nikolić A, Opinćal F, Ristanović M, Trifunović J, Knežević S, Radojkovic D (2017) Analysis of SMAD4 gene promoter methylation in pancreatic and endometrial cancer. Arch Oncol 23(2):17-19. https://doi.org/10.2298/AOO1 $702017 \mathrm{~N}$

21. Kovacevic Z, Chikhani S, Lui GYL, Sivagurunathan S, Richardson DR (2013) The iron-regulated metastasis suppressor NDRG1 targets NEDD4L, PTEN, and SMAD4 and inhibits the PI3K and Ras signaling pathways. Antioxid Redox Signal 18(8):874-887. https://doi.org/10.1 089/ars.2011.4273

22. Chung Y, Chan Wi Y, Kim Y, Bang SS, Yang J, Jang K, Min KW, Paik SS (2018) The Smad4/PTEN expression pattern predicts clinical outcomes in colorectal adenocarcinoma. J Pathol Transl Med 52(1):37-44. https://doi.org/10.4132/ jptm.2017.10.20

23. Greene FL, Sobin LH (2008) The staging of cancer: a retrospective and prospective appraisal. CA Cancer J Clin 58(3):180-190. https://doi.org/1 0.3322/CA.2008.0001

24. Cicco PD, Catani MV, Gasperi V, Sibilano M, Quaglietta M, Savini I (2019) Nutrition and breast cancer: a literature review on prevention, treatment and recurrence. Nutrients 11(7):1514. https://doi.org/10.3390/ nu11071514

25. Ibrahim AS, Khaled HM, Mikhail NN, Baraka H, Kamel H (2014) Cancer incidence in Egypt: results of the national population-based cancer registry program. J Cancer Epidemiol:2014

26. Marina M, Dragan J, Aleksandar M, Dragan S (2017) Early diagnosis and detection of breast cancer. J Technol Health Care 26:729-759

27. Locke WJ, Guanzon D, Ma C, Liew Y, Duesing KR, Fung KY, Ross JP (2019) DNA methylation cancer biomarkers: translation to the clinic. Front Genet 10:1150

28. Xu X, Ehdaie B, Ohara N, Yoshino T, Deng CX (2010) Synergistic action of Smad4 and PTEN in suppressing pancreatic ductal adenocarcinoma formation in mice. Oncogene 29(5):674-686. https://doi.org/10.1038/onc.2 009.375

29. Liu J, Cho SN, Akkanti B, Jin N, Mao J, Long W, Chen T, Zhang Y, Tang X, Wistub II, Creighton CJ, Kheradmand F, DeMayo FJ (2015) ErbB2 pathway activation upon Smad4 loss promotes lung tumor growth and metastasis. Cell Rep 10(9):1599-1613. https://doi.org/10.1016/j.celrep.201 5.02 .014

30. Li XB, Yang G, Zhu L, Tang YL, Zhang C, Ju Z, Yang X, Teng Y (2016) Gastric Lgr5 (+) stem cells are the cellular origin of invasive intestinaltype gastric cancer in mice. Cell Res 26(7):838-849. https://doi.org/10.1 038/cr.2016.47

31. Syria JC, Lee HY, Lee Jl, Wang L, Issa JP et al (2002) Lack of PTEN expression in non-small cell lung cancer could be related to promoter methylation. Clin Cancer Res 8:1178-1184

32. Kang YH, Lee HS, Kim WH (2002) Promoter methylation and silencing of PTEN in gastric carcinoma. Lab Investig 82(3):285-291. https://doi.org/10.103 8/labinvest.3780422

33. Yang HJ, Liu SW, Wang Y, Tsang CK, Ngan YS (2006) Differential DNA methylation profiles in gynecological cancers and correlation with clinicpathological data. BMC Cancer 6(1):212. https://doi.org/10.1186/1471-24076-212

34. Salvesen HB, MacDonald N, Ryan A, Jacobs IJ, Lynch ED, Akslen LA, Das $S$ (2001) PTEN methylation is associated with advanced stage and microsatellite instability in endometrial carcinoma. Int J Cancer 91(1):2226. https://doi.org/10.1002/1097-0215(20010101)91:1<22::AID-IJC1002>3.0. $\mathrm{CO} ; 2-\mathrm{S}$

35. Wu L, Shen Y, Peng X, Zhang S, Wang M, Xu G, Zheng X, Wang J, Lu C (2016) Aberrant promoter methylation of cancer-related genes in human breast cancer. Oncol Lett 12(6):5145-5155. https://doi.org/10.3 892/ol.2016.5351

36. Yari K, Payandeh M, Rahimi Z (2015) Association of the hypermethylation status of PTEN tumor suppressor gene with the risk of breast cancer among Kurdish population from Western Iran. Int Soc Oncol BioMarkers (ISOBM)

37. Kazim Z, Wahabi K, Perwez A, Lal P, Rizvi MA (2019) PTEN genetic and epigenetic alterations define distinct subgroups in North Indian breast cancer patients. Asian Pac J Cancer Prev 20(1):269-276. https://doi.org/10.31 557/APJCP.2019.201.269

38. Romero-Garcia S, Prado-Garcia H, Carlos-Reyes A (2020) Role of DNA methylation in the resistance to therapy in solid Tumors. Front Oncol 7(10): 1152

39. Ali NA, McKay MJ, Molloy MP (2010) Proteomics of Smad4 regulated transforming growth factor-beta signalling in colon cancer cells. Mol BioSystems 6(11):2332-2338. https://doi.org/10.1039/c0mb00016g

40. Yoo SY, Lee JA, Shin Y, Cho NY, Bae JM, Kang GH (2019) Clinicopathological characterization and prognostic implication of SMAD4 expression in colorectal carcinoma. J Pathol Transl Med 53(5):289-297. https://doi.org/1 0.4132/jptm.2019.06.07

41. Wilentz R, lacobuzio-Donahue C, Argani P, McCarthy DM, Parsons JL, Yeo CJ, Kern SE, Hruban RH (2000) Loss of expression of Dpc4 in pancreatic intraepithelial neoplasia: evidence that DPC4 inactivation occurs late in neoplastic progression. Cancer Res 60(7):2002-2006

42. Liu S, Foulkes WD, Leung S, Gao D, Lau S, Kos Z, Nielsen TO (2014) Prognostic significance of FOXP3+ tumor-infiltrating lymphocytes in breast cancer depends on estrogen receptor and human epidermal growth factor receptor-2 expression status and concurrent cytotoxic Tcell infiltration. Breast Cancer Res 16(5):432. https://doi.org/10.1186/s13 058-014-0432-8

43. Deckers M, van Dinther M, Buijs J, Que I, Löwik C, van der Pluijm G, ten Dijke $P$ (2006) The tumor suppressor Smad4 is required for transforming growth factor beta-induced epithelial to mesenchymal transition and bone metastasis of breast cancer cells. Cancer Res 66(4):2202-2209. https://doi. org/10.1158/0008-5472.CAN-05-3560

44. Li Q, Wu L, Oelschlager DK, Wan M, Stockard CR, Grizzle WE, Wang N, Chen $\mathrm{H}$, Sun $Y$, Cao X (2005) Smad4 inhibits tumor growth by inducing apoptosis in estrogen receptor-alpha-positive breast cancer cells. J Biol Chem 280(29): 27022-27028. https://doi.org/10.1074/jbc.M505071200

45. Roth S, Laiho P, Salovaara R, Launonen V, Aaltonen LA (2000) No SMAD4 hypermethylation in colorectal cancer. Br J Cancer 83(8):1015-1019. https:// doi.org/10.1054/bjoc.2000.1387

46. Sameer AS, Siddiqi MA (2011) SMAD4 promoter hypermethylation in Kashmiri colorectal cancer cases. Saudi J Gastroenterol 17(4):297. https://doi. org/10.4103/1319-3767.82591

47. Fotouhi $O$, Adel Fahmideh M, Kjellman M, Sulaiman L, Hoog A, Zedenius J, Hashemi J, Larsson C (2014) Global hypomethylation and 
promoter methylation in small intestinal neuroendocrine tumors: an in vivo and in vitro study. Epigenetics 9(7):987-997. https://doi.org/10.41 61/epi.28936

48. Onwuegbusi BA, Aitchison A, Chin SF, Kranjac T, Mills I, Huang Y, Lao-Sirieix P, Caldas C, Fitzgerald RC (2006) Impaired transforming growth factor beta signalling in Barrett's carcinogenesis due to frequent SMAD4 inactivation. Gut 55(6):764-774. https://doi.org/10.1136/gut.2005.076430

\section{Publisher's Note}

Springer Nature remains neutral with regard to jurisdictional claims in published maps and institutional affiliations.

Submit your manuscript to a SpringerOpen ${ }^{\mathcal{O}}$ journal and benefit from:

- Convenient online submission

Rigorous peer review

- Open access: articles freely available online

High visibility within the field

- Retaining the copyright to your article

Submit your next manuscript at $\boldsymbol{\nabla}$ springeropen.com 